\title{
PROGRAM PENGABDIAN KEPADA MASYRAKAT: PENANAMAN NASIONALISME DALAM MENCEGAH AKSI RADIKALISME KEPADA ANAK: PERWUJUDAN KONKRET PENCAPAIAN SDGS 16
}

\author{
Denik Iswardani Witarti ${ }^{1)}$, Anggun Puspitasari ${ }^{2)}$, dan Arin Fithriana ${ }^{3)}$ \\ ${ }^{1}$ Ilmu Komunikasi, Fakultas Ilmu Komunikasi, Universitas Budi Luhur \\ ${ }^{2,3} \mathrm{Ilmu}$ Hubungan Internasional, Fakultas Ilmu Sosial dan Ilmu Politik, Universitas Budi Luhur \\ 1,2,3 Jl. Ciledug Raya, Petukangan Utara, Kec. Pesanggrahan, Kota Jakarta Selatan, Jakarta, 12260 \\ E-mail : denik.iswardani@budiluhur.ac.id ${ }^{1)}$, anggun.puspitasari@budoluhur.ac.id ${ }^{2}$, arin.fithriana@ budiluhur.ac.id ${ }^{3)}$
}

\begin{abstract}
ABSTRAK
Tujuan Sustainable Development Goals (SDGs) ke-16 merupakan salah satu tujuan utama dalam pencapaian SDGs sampai dengan tahun 2030. Tujuan 16 berupaya menciptakan masyarakat yang inklusif dan damai (Peace), terwujudnya penegakan keadilan (justice) dengan menyediakan akses keadilan untuk semua, serta membangun institusi yang tangguh (strong institutions). Dalam tujuan 16 ini, komponen Peace merupakan tujuan utama, namun pencapaiannya terhambat dengan masalah-masalah keamanan yanng ada di Indonesia, salah satunya adalah aksi terorisme. Indonesia bukan hanya dikenal sebagai negara yang menjadi sasaran tindakan teroris, namun juga masuk negara pemasok teroris. Dengan adanya aksi terorisme yang melibatkan anak, maka anak berada pada posisi yang rentan dan mudah dimanipulasi bahkan dieksploitasi untuk bertindak radikal sebagaimana teroris. Dalam pencapaian SDGs 16, pemerintah membutuhkan bantuan dari segenap unsur-unsur yang ada di dalam negara. Kajian ini merupakan hasil dari kegiatan PKM (Pengabdian Kepada Masyarakat) yang menitikberatkan pada upaya-upaya yang bisa dilakukan oleh bagian dari masyarakat untuk mencapai target SDGs ke 16, yaitu upaya menanamkan rasa nasionalisme kepada anak usia dini dan dibatasi pada upaya yang dilakukan di wilayah hunian urban di daerah Jakarta Selatan, Apartemen Gateway. Penanaman nilai-nilai nasionalisme dengan metode yang menarik yaitu dengan perlombaan melukis tematik menciptakan antusiasme tersendiri bagi anak-anak usia dini tersebut akan negara bangsanya. Penanaman sikap nasionalisme ini diharapkan dapat menjadi modal bagi anak-anak untuk membentengi diri dari sikap radikalisme dan menumbuhkan sikap kepekaan dan kepedulian sesamanya.
\end{abstract}

Kata Kunci: SDGs, Nasionalisme, Radikalisme, Anak, Jakarta

\section{PENDAHULUAN}

Terorisme merupakan kejahatan luar biasa yang ada di dunia ini. Aksi terorisme adalah tindakan membuat ancaman dan ketakutan yang melanggar Hak Asasi Manusia. Setiap negara atau kelompok memberikan batasan yang berbeda-beda berkenaan dengan definisi terorisme. Namun demikian ke semuanya sepakat bahwa terorisme adalah aktivitas yang mengancam dan memberikan ketakutan pada kehidupan manusia. Seluruh dunia sepakat bahwa tindakan terorisme tidak dapat dibenarkan dan menjadi ancaman kehidupan semesta. Kehidupan semesta karena dampak tindakan terorisme tidak hanya mengancam kehidupan manusia, namun juga kehidupan makhluk dan lingkungan secara umum. Dampak yang diakibatkan dari tindakan terorisme merugikan semua pihak, baik jiwa dan raga, fisik maupun psikis yang berkepanjangan. Menghilangkan rasa takut dan khawatir bagi korban tindakan teroris, membutuhkan waktu yang lama. Demikian juga dengan rehabilitasi dan rekonstruksi pasca tindakan teroris juga membutuhkan waktu, dana dan pikiran yang lama. Dampak tindakan terorisme tidak dapat dilupakan. (Djelantik, S. 2010)
Indonesia bukan hanya dikenal sebagai negara yang menjadi sasaran tindakan teroris, namun juga masuk negara pemasok teroris. Menyadari hal tersebut, pemerintah Indonesia tidak tinggal diam dalam menanggulangi dan memberantas terorisme. Menyikapi hal tersebut pemerintah Indonesia telah mengadopsi Konvensi Melawan Terorisme Internasional yang diadopsi oleh OKI pada 1999 yang mendefinisikan terorisme sebagai "tindak kekerasan atau ancaman secara individual atau kelompok dengan tujuan meneror orangorang atau mengancam untuk melukai mereka atau membahayakan kehidupan, kehormatan, kebebasan, keamanan, atau hak-hak mereka, atau membuat kerusakan, menduduki, atau merebut fasilitas publik atau properti pribadi, atau membahayakan sumber daya nasional, atau fasilitas internasional, atau mengancam stabilitas, persatuan teritorial, kesatuan politik, atau kedaulatan negara".

Adopsi ini menunjukkan bahwa telah sejak lama Indonesia telah lama memberikan perhatian pada pencegahan dan penanggulangan terorisme. DPR juga telah menyetujui Revisi UU tentang Anti Terorisme menjadi Undang-undang meskipun melewati polemik yang cukup panjang. Pemerintah memandang 
pengesahan merupakan hal yang mendesak mengingat aksi terorisme di Indonesia telah melewati batas dan mengalami perubahan bentuk (Mubarak, Z. 2013).

Keterlibatan perempuan dan anak dalam rentetan teror bom di tiga gereja di Surabaya, Jawa Timur, pada Minggu 13 Mei 2018 menunjukkan bahwa ada perubahan pola aksi terorisme (Tamawiwy, A. C. 2019). Meski bukan yang pertama dalam sejarah aksi terorisme, keterlibatan perempuan dinilai sangat efektif. Kapolri Jenderal Tito Karnavian mengatakan keterlibatan perempuan dalam aksi terorisme pertama kali dilakukan pada tahun 1991. Seorang perempuan bernama Dhanu melakukan aksi bom bunuh diri yang menewaskan Perdana Menteri India Rajiv Gandhi. Fenomena keterlibatan perempuan ini dilakukan Liberation Tigers of Tamil Eelam (LTTE) Tamil Tiger, dengan mengalungkan dan duduk untuk bersimpuh di kaki Rajiv Gandhi kemudian meledakkan bom bunuh diri. Menurut Tito Karnavian, cara tersebut kemudian di-copy oleh kelompok teror yang lain. Tito juga mengatakan keterlibatan perempuan merupakan cara efektif untuk menghindari kejaran polisi. Metode untuk mengelak, menghindari deteksi aparat, karena laki-laki mudah untuk sasaran deteksi, perempuan tidak terdeteksi. (CNN Indonesia, 2018)

Tiga keluarga terlibat dalam aksi teror di Jawa Timur pada akhir Mei 2018. Keterlibatan istri dan anak-anak usia dini dalam aksi bom bunuh diri menjadi modus baru dan semakin memperkuat peran perempuan dalam aksi terorisme. Pemerhati isu gender dan radikalisme, Lies Marcoes, memandang fenomena bom Surabaya yang melibatkan satu keluarga: suami, istri dan anak-anaknya membuktikan peran perempuan dalam gerakan radikal tak lagi bersifat individual, melainkan sebagai pelaku utama yang memiliki kekuatan yang bahkan melibatkan anaknya sendiri sebagai pelaku teror dan kekerasan. Memang, pelibatan perempuan sebagai pelaku bom bunuh diri bukan kali pertama. Namun, Kapolri Jenderal Tito mengungkapkan ini untuk pertama kalinya anak di bawah umur menjadi pelaku bom bunuh diri. Pelaku melibatkan istrinya serta empat orang anaknya -dua di antaranya perempuan berusia sembilan dan 12 tahun, menjadi pengebom bunuh diri di gereja Santa Maria Tak Bercela, gereja Pantekosta dan gereja GKI Diponegoro. Akibat aksi tersebut, semua pelaku mati seketika. (Masu, R. R. 2019)

Keterlibatan anak-anak dalam aksi jihad dilakukan untuk mengelabuhi para aparat keamanan. Penelitian yang dilakukan Institute for Policy of Conflict (IPAC) tahun 2018 menunjukkan perempuan dan anak-anak usia dini Indonesia mulai mengambil peran dalam tindak ekstremisme dan radikalisme, bahkan beberapa dari mereka ingin menjadi pembom bunuh diri. Aksi terorisme yang terjadi di Jawa Timur yang masingmasing dilakukan oleh satu keluarga beserta anak-anak mereka yang masih di bawah umur, membuat Lies Marcoes memandang telah terjadi perubahan besar dalam pelibatan keluarga dalam aksi teror. Melibatkan anak-anak di bawah umur, menunjukkan perubahan besar dalam peta aksi teror. Kini perempuan menjadi pelaku aktif dan sangat mungkin memanipulasi anak untuk menjadi pelaku. Namun, Ketua Komisi Perlindungan Anak Indonesia (KPAI) Susanto menganggap pelibatan langsung anak di bawah umur dalam aksi jihad tidak serta merta membuktikan bocah di bawah umur ini terdoktrinasi orang tuanya. (Rahayu, S. W, Sugianto, F., \& Velicya, V. 2020)

Berkaca dari kasus-kasus tersebut, perlu diperhatikan potensi indoktrinasi radikalisme kepada anak. Namun, ini akan sulit dicegah bila pelaku indoktrinasi adalah orang tua sang anak sendiri. Risiko indoktrinasi radikalisme lebih mudah dibatasi dan dicegah bila pelaku adalah pihak lain yang bukan orang tua. Sangat berbahaya apabila ideologi radikalisme masuk ke ruangruang keluarga (Rachma, A. D. 2020).

Selama ini pemahaman jihad hanya dilakukan oleh kepala keluarga atau laki-laki. Namun muncul perspektif baru yang memungkinkan masuk 'surga' satu keluarga. Sementara itu, mantan teroris Nasir Abbas berpendapat perempuan memiliki peran besar untuk mencegah terjadinya aksi terorisme, sebab perempuan dapat menjadi sosok yang paling rasional kepada pria. Oleh sebab itu, kasus Bom di Sidoarjo ataupun Surabaya menjadi momentum untuk meningkatkan kepekaan kepada tetangga sekitar. Jika melihat seorang anak yang dilarang bergaul oleh keluarganya bisa langsung menghubungi KPAI ataupun KPAD dan Kepolisian. Pemerintah perlu melakukan tindakan antisipatif dengan inovasi pendidikan penangkal radikalisme. (Nimah, R., Anshori, I., \& Ikhwanuddin, M., 2019)

Kepekaan masyarakat Indonesia kepada tetangga sekitar telah mengalami penurunan. Penurunan ini terutama terjadi di wilayah urban dengan densitas penduduk yang berasal dari latar belakang yang berbedabeda. Pemenuhan kebutuhan, tuntutan hidup, mobilitas yang tinggi berpengaruh terhadap pola interaksi masyarakat urban. Berbagai persoalan yang dialami masyarakat turut mempengaruhi kepekaan dan kepedulian masyarakat kepada lingkungan sekitar. (Hiratsuka, M., Nakama, E., Satriadi, T., Fauzi, H., Aryadi, M., \& Morikawa, Y, 2019) Beban persoalan hidup yang dihadapi masyarakat mengakibatkan masyarakat cenderung untuk memfokuskan penyelesaian masalah mereka sendiri. Kecenderungan ini pula yang kemudian berpengaruh pada kepekaan lingkungan sekitar.

Tidak mengherankan apabila saat ini masyarakat urban yang tinggal di kawasan padat penduduk justru tidak saling mengenal satu sama lain secara nyata (Apromico, A., Soponyono, E. S., \& Hafidz, J., 2020).

Kondisi ini sangatlah ironis mengingat Indonesia merupakan negara kesatuan yang menekankan persatuan, toleransi dan kerja sama antar anggota masyarakat. Menurunnya kepekaan ini berpotensi pada perpecahan yang menimbulkan perseteruan antar anggota masyarakat. Indonesia memiliki suku bangsa dan agama 
yang beragam dengan nilai yang berbeda-beda. Dibutuhkan toleransi untuk dapat mempersatukan beragamnya perbedaan tersebut, namun toleransi tidak akan dapat terwujud jika tanpa adanya rasa kepedulian dan kepekaan terhadap lingkungan sekitar. Kesalahpahaman dapat ditimbulkan dari kondisi di atas. Kesalahpahaman berpotensi pada berkembangnya konflik. Apabila pemerintah tidak mampu mengatasi ini, maka tidak menutup kemungkinan akan berpengaruh terhadap rasa nasionalisme kepada negara dan bangsa. Kekhawatiran akan menurunnya sikap nasionalisme akan membahayakan kehidupan berbangsa dan bernegara, Indonesia (Ihsan, R, 2019).

Dalam perkembangannya, hal ini sejalan dengan Program Sustainable Development Goals (SDGs). SGDs resmi diumumkan pada tanggal 25-27 September 2015 melalui sidang umum Majelis Umum PBB yang dihadiri oleh perwakilan 193 negara anggota. Program pembangunan universal SDGs secara serentak resmi berlaku (entry into force) bagi setiap negara pengadopsi sejak bulan Januari, 2016 hingga pada tahun 2030. Pada target ke 16 SDGs pencapaian yang harus dilakukan meliputi mempromosikan masyarakat yang damai dan inklusif demi pembangunan berkelanjutan, menyediakan akses keadilan bagi semua dan membangun lembaga yang efektif, akuntable dan inklusif di seluruh tingkatan. Dalam kajian ini, salah satu program yang hendak disasar adalah membangun masyarakat yang damai dan inkusif yang ditanamkan pada anak sejak dini. (McDermott, C. L., 2019).

Indonesia menjadi salah satu negara yang ikut mendukung dan menyepakati program pembangunan SDGs. Komitmen Indonesia dalam menyukseskan tujuan-tujuan yang terdapat pada program SDGs terlihat dari penandatanganan Peraturan Presiden (Perpres) Nomor 59 Tahun 2017 Tentang Pelaksanaan Pencapaian Tujuan Pembangunan Berkelanjutan oleh Presiden Jokowi pada bulan Juli, 2017 silam. Perpres tersebut menjadi tonggak utama dan dasar hukum yang menetapkan struktur dan mekanisme tata kelola SDGs nasional terkait dengan perencanaan, penganggaran, pembiayaan, pemantauan dan pelaporan (Sudarmonowati, E., 2019).

Dalam pencapaian SDGs, pemerintah membutuhkan bantuan dari segenap unsur-unsur yang ada di dalam negara. Kajian ini menitikberatkan pada upaya-upaya yang bisa dilakukan oleh bagian dari masyarakat untuk mencapai target SDGs ke 16, yaitu upaya menanamkan rasa nasionalisme kepada anak usia dini. Sebagaimana dijelaskan di atas bahwa dengan adanya aksi terorisme yang melibatkan anak, maka anak berada pada posisi yang rentan dan mudah dimanipulasi bahkan di eksploitasi untuk bertindak radikal sebagaimana teroris. Disisi lain, anak merupakan generasi penerus bagi keberlangsungan bangsa dan negara Indonesia. Sehingga indoktrinasi yang diberikan idealnya indoktrinasi positif untuk mengembangkan sikap nasionalisme dalam menjaga keutuhan bangsa dan negara Indonesia (Sumbulah, U., 2019).

\section{RUANG LINGKUP}

Kajian ini dibatasi pada upaya yang dilakukan di wilayah hunian urban di daerah Jakarta Selatan. Sebagaimana dijelaskan sebelumnya bahwa untuk mencegah tindakan terorisme, maka salah satu yang dapat dilakukan adalah dengan meningkatkan kepekaan antar masyarakat kepada lingkungan sekitar. Dengan banyaknya pemukiman hunian vertikal di lingkungan urban, seringkali identik dengan kondisi sosial masyarakat yang lebih memfokuskan pada aktivitas pemenuhan dan penyelesaian masalah individu atau cenderung individualistis. Kondisi ini yang mendorong kurangnya kepekaan dan kepedulian terhadap lingkungan sekitar.

Oleh karena itu pada kajian ini penulis berusaha untuk melihat efektivitas dari penyelenggaraan kegiatan Pengabdian Kepada Masyarakat dengan tema penanaman sikap nasionalisme untuk mencegah aksi radikalisme kepada anak di "Gateway" Pesanggarahan Jakarta Selatan untuk membantu pemerintah dalam ketercapaian SDGs target ke 16. Gateway Pesanggrahan merupakan pemukiman warga dengan densitas tinggi dengan beragam latar belakang. Terletak di jalan Raya Ciledug no 15, Jakarta Selatan atau Ciledug Raya, RT.004/RW.03, 12270, Petukangan Selatan, Pesanggrahan, Jakarta Selatan, merupakan wilayah yang cukup padat karena berdekatan dengan lokasi pusat aktivitas masyarakat.

Lokasi yang sangat strategis ini menjadi perhatian warga masyarakat yang membutuhkan pemukiman. Sebagai hunian urban, Gateway memiliki tantangan dalam mengelola berbagai macam karakter penghuni. Sehingga pengelola bersikap selektif dan berhati-hati dalam menerima calon pengguna hunian. Terlebih dengan adanya peristiwa yang dimaksud tersebut maka diperlukan perhatian khusus.

Sebagai hunian keluarga, penghuni Gateway di dalamnya juga termasuk anak-anak. Anak-anak sebagai generasi penerus bangsa dan negara perlu mendapatkan pemahaman nasionalisme sebagai bentuk cinta tanah air dan bangsa melalui sikap toleransi. Kegiatan dibatasi pada anak di bawah umur dengan rentang 4-8 tahun (TK sampai sekolah dasar). Sebagaimana dijelaskan di atas bahwa dengan adanya aksi terorisme yang melibatkan anak, maka anak berada pada posisi yang rentan dan mudah dimanipulasi bahkan di eksploitasi untuk bertindak radikal sebagaimana teroris.

Dengan penanaman nilai-nilai nasionalisme dengan metode yang menarik, tentunya akan menciptakan antusiasme tersendiri bagi anak-anak usia dini tersebut akan negara bangsanya. Penanaman sikap nasionalisme ini diharapkan dapat menjadi modal bagi anak-anak untuk membentengi diri dari sikap radikalisme dan menumbuhkan sikap kepekaan dan kepedulian 
sesamanya. Pada akhirnya sikap tersebut menjadi modal bagi Indonesia untuk tetap berdiri sebagai negara besar

\section{BAHAN DAN METODE}

Tulisan ini menggunakan pendekatan kualitatif yang berfokus pada analisis deskriptif dalam membahas temuan penelitian yang dilakukan (Bryman, 2012). Dawson (2007) menyatakan bahwa penelitian kualitatif bertujuan mengeksplorasi perilaku, sikap, dan pengalaman subjek dalam penelitian. Metode ini digunakan untuk mencari pemikiran secara mendalam melalui observasi langsung di Apartment Gateway.

Guna mengukur hasil pembangunan yang ada dalam SDGs, dilakukan proses tindak lanjut dan pelaporan (follow up and review) dengan mendasarkan pada rangkaian indikator. Rangkaian indikator dipersiapkan baik pada level global, regional maupun nasional. Upaya mengidentifikasi kerangka indikator global untuk tujuan dan sasaran SDGs, Komisi Statistik PBB membentuk Inter-Agency Expert Group (IAEG) on SDGs Indicators pada bulan Maret 2015. Dalam proses penyusunannya, IAEG telah melakukan beberapa pertemuan dan konsultasi dengan berbagai pihak hingga akhirnya menghasilkan tepatnya 242 indikator global. (Jayanti, E., Muhammad, S., Nazamuddin, B., Zulham, T., 2019).

Adapun jumlah target dan indikator global yang disetujui untuk tiap goal dapat dilihat dalam tabel 1.

Tabel 1. Jumlah Sasaran dan Indikator MasingMasing Tujuan SDGs

\begin{tabular}{|c|c|c|}
\hline & Sasaran & Indikator \\
\hline Goal 1 & 7 & 12 \\
\hline Goal 2 & 8 & 14 \\
\hline Goal 3 & 13 & 27 \\
\hline Goal 4 & 10 & 11 \\
\hline Goal 5 & 9 & 14 \\
\hline Goal 6 & 8 & 11 \\
\hline Goal 7 & 5 & 6 \\
\hline Goal 8 & 12 & 17 \\
\hline Goal 9 & 8 & 12 \\
\hline Goal 10 & 10 & 11 \\
\hline Goal 11 & 10 & 15 \\
\hline Goal 12 & 11 & 13 \\
\hline Goal 13 & 5 & 7 \\
\hline Goal 14 & 10 & 10 \\
\hline Goal 15 & 12 & 14 \\
\hline Goal 16 & 12 & 23 \\
\hline Goal 17 & 19 & 25 \\
\hline Jumlah & 169 & 242 \\
\hline
\end{tabular}

Tujuan dari SDGs nomor 16 adalah meningkatkan perdamaian termasuk masyarakat untuk pembangunan berkelanjutan, menyediakan akses untuk keadilan bagi semua orang termasuk lembaga dan bertanggung jawab untuk seluruh kalangan, serta membangun institusi yang efektif, akuntabel, dan inklusif di seluruh tingkatan. Tujuan keenam belas, mempromosikan perdamaian dan masyarakat toleran untuk pembangunan berkelanjutan, memberikan akses untuk keadilan bagi semua, serta membangun institusi yang efektif, terbuka, dan bisa dipertanggungjawabkan.

Target-targetnya antara lain:

1. Mengurangi segala bentuk kekerasan dan semua kejahatan yang mengakibatkan kematian.

2. Mengakhiri pelecehan, eksploitasi, perdagangan, serta segala bentuk kekerasan dan penyiksaan terhadap anak-anak.

3. Mempromosikan kesepakatan secara nasional dan internasional dalam memastikan keadilan untuk semua pihak.

4. Mengurangi praktik keuangan yang kotor, memperkuat perbaikan dan pengembalian aset-aset curian, serta melawan segala bentuk kejahatan yang terorganisir.

5. Mengurangi korupsi dan penyuapan dalam segala bentuk.

6. Mengembangkan institusi yang transparan, efektif, dan bisa dipertanggungjawabkan.

7. Memastikan pengambilan keputusan yang responsif, terbuka, dan partisipatif di setiap level.

8. Mengembangkan dan memperkuat partisipasi negaranegara sedang berkembang dalam tata kelola pemerintahan global.

9. Memberikan identitas legal, termasuk dalam kaitannya dengan registrasi kelahiran.

10. Memastikan akses publik atas informasi dan melindungi kebebasan dasar sesuai dengan kesepakatan internasional dan legislasi nasional.

11. Memperkuat institusi nasional melalui kerja sama internasional, terutama di negara-negara berkembang untuk mencegah terjadinya kekerasan, serta melawan terorisme dan kejahatan.

12. Mempromosikan serta mendorong hukum dan kebijakan yang tidak diskriminatif.

Dalam kajian ini, target yang difokuskan adalah poin 1 dan 2. Ketercapaiannya dapat dilihat secara kualitatif dengan pendekatan langsung kepada para peserta kegiatan PKM. Data dan fakta di lapangan kemudian digunakan penulis untuk melaku-kan analisis secara teoretis. Untuk validasi data, sumber- sumber dan datadata yang berbeda ditrianggulasi dan digunakan sebagai basis analisis.

\section{PEMBAHASAN}

SDGs merupakan inisiatif global yang bertujuan untuk menciptakan kehidupan manusia menjadi lebih baik dalam aspek sosial dan ekonomi serta dapat bersinergi dengan lingkungan. Pada penyusunannya, disadari penuh bahwa inisiatif global ini tidak dapat menampilkan adanya implementasi di tingkat regional dan nasional. SDGs di tingkat regional dan nasional pun perlu meneguhkan kembali semangat dan nilai SDGs yang inklusif dan partisipatif sebagaimana yang telah dibangun dalam SDGs tingkat global. Pengawasan yang dilakukan oleh negara bersifat sangat krusial dalam 
memastikan bahwa pelaksanaan SDGs didasarkan pada pendekatan dan strategi yang holistik antara pembangunan ekonomi, inklusi sosial, dan keberlanjutan lingkungan dengan tetap mengedepankan pada karakteristik dan prioritas tiap-tiap negara (Hadi, S. P., 2019).

Pada kegiatan PKM ini penyelenggara menggunakan Metode kombinasi antara Tanya jawab, permainan dan perlombaan. Metode ini dilaksanakan berkaitan dengan tema PKM berupa pemahaman dan sikap nasionalisme untuk mencegah aksi radikalisme. Selain itu karena yang menjadi peserta pada objek sasaran adalah anak-anak penghuni Gateway, maka pemilihan metode menjadi pertimbangan untuk dapat disampaikan secara ringan dan menyenangkan.

Pelaksanaan kegiatan yang berdekatan dengan rangkaian perayaan hari Kemerdekaan RI ke-73, maka metode perlombaan menjadi salah satu cara untuk menarik minat peserta sekaligus sebagai evaluasi dalam penyampaian materi melalui Tanya jawab berkaitan dengan sikap nasionalisme. Melalui perlombaan tentang kepekaan, kepedulian lingkungan sekitar diharapkan membentuk pemahaman tentang nasionalisme dan mencegah radikalisme pada anak secara sederhana. Secara lebih rinci metode kegiatan akan dibagi menjadi dua pendekatan, yaitu pengenalan nilai-nilai nasionalisme berupa seminar untuk kaum ibu dan anak yang akan dilanjutkan dengan lomba melukis untuk ibu dan anak. Dengan demikian, pendekatan ini dapat mengakomodir kebutuhan ibu dan anak mengenai pengenalan nilai-nilai dasar nasionalisme dengan sederhana dan menyenangkan.

Anak-anak akan melukis pada kanvas sedangkan para ibu akan melukis dengan media Tote Bag dengan dibimbing oleh mahasiswa dan pelukis senior yang menjadi fasilitator. Fasilitator akan dibekali dengan tema kegiatan untuk mengarahkan. Lokasi lomba dan workshop akan diadakan di lantai 1 Rusunawa Gateway persis di depan kolam renang. Tempat ini dipilih karena merupakan satu-satunya tempat terluas dan bersifat terbuka.

Tahap awal dimulai dengan diskusi pengenalan nilai kebangsaan dan nasionalisme oleh penyelenggara kepada ibu dan anak. Pada tahap awal ini penyelenggara akan mengenalkan pada ibu mengenai nilai-nilai kebangsaan dan nasionalisme serta bahaya munculnya sikap radikalisme secara sederhana sehingga dapat disampaikan kembali kepada anak-anak dengan cara yang lebih persuasif. Pada akhir seminar dibuka sesi Tanya jawab sebagai media sharing atau berbagi para ibu mengenai kondisi di sekitarnya pada gambar 1 .

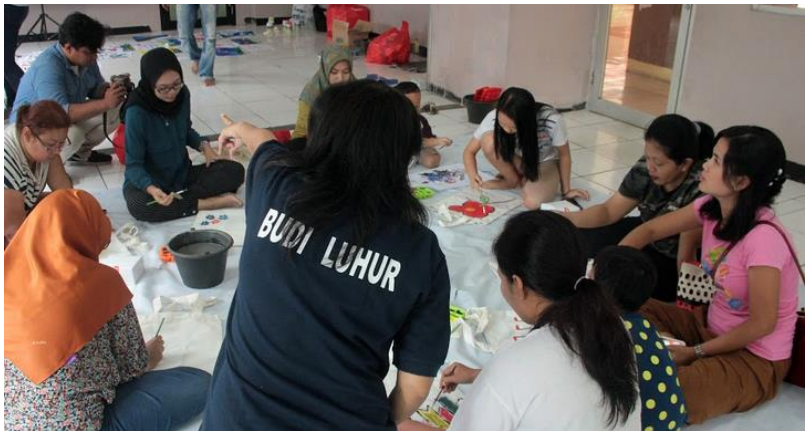

Gambar 1. Diskusi Disampaikan Oleh Narasumber

Acara selanjutnya adalah perlombaan melukis untuk anak yang akan dipandu fasilitator. Fasilitator yang merupakan mahasiswa dan pelukis senior akan mengajarkan anak-anak melukis di atas media kanvas yang sesuai dengan tema mengenai nilai-nilai kebangsaan. Pada tahap ini penyelenggara dapat melihat sejauh mana anak-anak memahami nilai kebangsaan mereka melalui lukisan yang mereka buat dengan bertanya langsung apa arti dari lukisan mereka, dengan demikian nilai-nilai kebersamaan dan toleransi akan lebih mudah untuk ditanamkan pada gambar 2 .

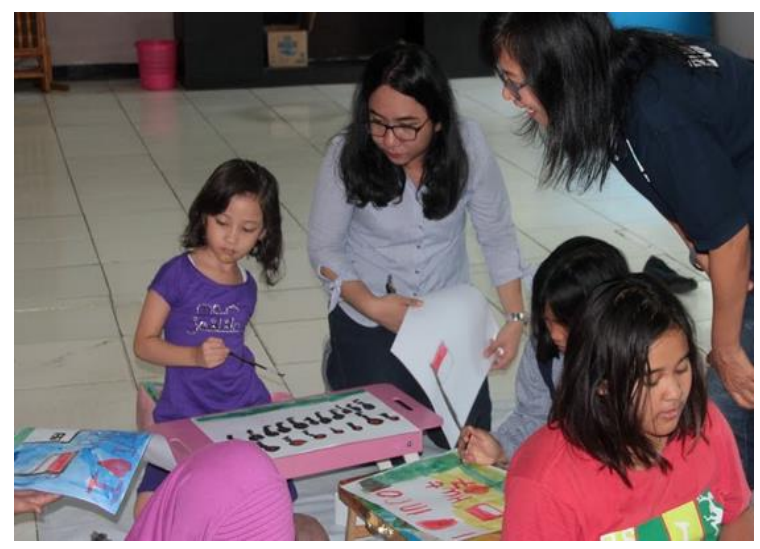

Gambar 2. Suasana Sesi Perlombaan Melukis

Dalam gambar 2. penyelenggara mendampingi para peserta yang sedang melukis sekaligus menanamkan nilai-nilai toleransi, cinta negara, dan anti radikalisme dengan persuasif sehingga dapat dituangkan dalam lukisan mereka. Anak-anak juga dapat mengonsultasikan lukisan mereka kepada narasumber. Dalam tahap ini narasumber dapat melihat bahwa antusiasme anak-anak dalam melihat nilai-nilai kebangsaan dan toleransi sangatlah besar.

Sebelum sesi melukis anak-anak berakhir, anak-anak diminta untuk mempresentasikan hasil karyanya dan menceritakan arti dari lukisannya pada gambar 3 . 


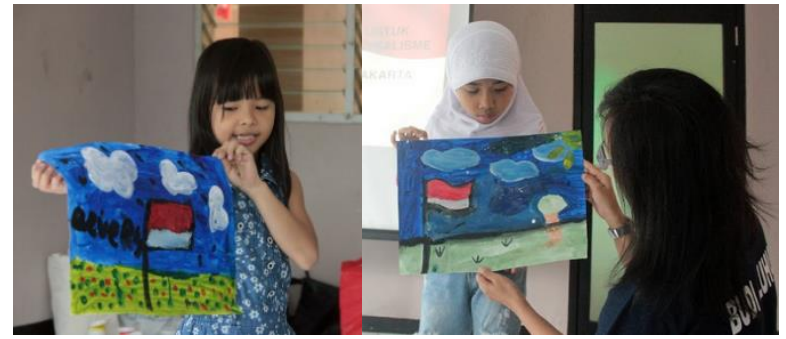

Gambar 3. Anak-anak Mempresentasikan Karyanya

Penyelenggara melihat bahwa penanaman nilai-nilai kebangsaan dan nasionalisme dapat disampaikan secara efektif melalui media lukis yang digemari anak-anak. Anak-anak menyampaikan kecintaannya terhadap negara sehingga sikap cinta tanah air tersebut merupakan langkah awal dalam pencegahan terhadap masuknya nilai-nilai radikalisme oleh pihak-pihak radikal.

Setelah sesi melukis, ibu-ibu juga diminta untuk mempresentasikan hasil karyanya. Berbeda dengan para anak, pada sesi presentasi pada ibu, dapat terlihat pemahaman yang lebih mendalam. Para ibu berharap, pemerintah dapat segera menyelesaikan permasalahan yang terkait dengan isu-isu radikalisme dengan tanggap. Isu radikalisme menjadi perhatian khusus para ibu mengingat tempat hunian mereka bersifat heterogen. Para ibu berkomitmen untuk mengajarkan anaknya nilainilai toleransi, cinta kasih dan nilai-nilai nasionalisme pada anak mereka.

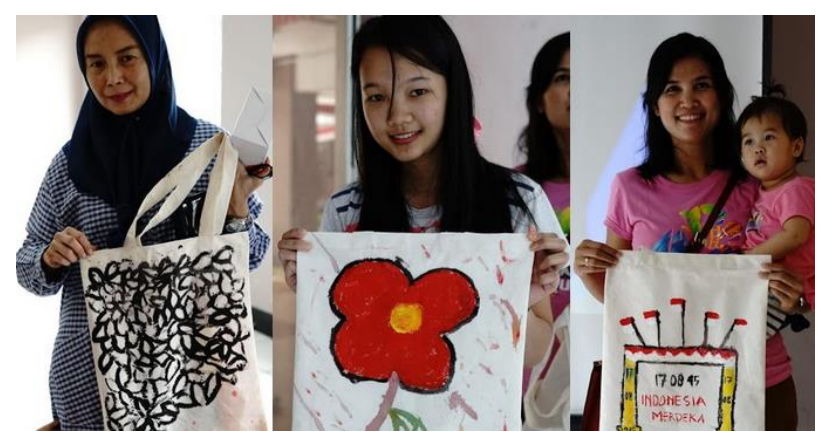

Gambar 4. Partisipasi Ibu-ibu dari Peserta Anak

Melalui perlombaan tentang kepekaan, kepedulian lingkungan sekitar diharapkan membentuk pemahaman tentang nasionalisme dan mencegah radikalisme pada anak secara sederhana. Dengan demikian, pendekatan ini dapat mengakomodir kebutuhan ibu dan anak mengenai pengenalan nilai-nilai dasar nasionalisme dengan sederhana dan menyenangkan.

\section{KESIMPULAN}

Kajian ini merupakan tinjauan hasil dari Kegiatan Pengabdian Kepada Masyarakat (PKM) yang disusun sebagai sumbangan nyata kampus Universitas Budi Luhur untuk mengenalkan lebih luas mengenai Penanaman Nasionalisme Untuk Mencegah Aksi Radikalisme Kepada Anak Di "Gateway" Pesanggarahan Jakarta Selatan. Pemilihan lokasi yang berdekatan dengan kampus Universitas Budi Luhur sebagai bentuk kepedulian dan kepekaan kepada lingkungan sekitar. Ini pula yang akan dikembangkan di lokasi sasaran sebagai tanggung jawab praktis dan akademis perguruan tinggi.

Penanaman nasionalisme ini juga sebagai bentuk upaya pencegahan aksi radikalisme yang melibatkan anak-anak. Penanaman ini diharapkan mampu memberikan pemahaman pada kepekaan dan kepedulian anak atas manipulasi radikalisme yang akan merugikan masyarakat. Kegiatan yang dilakukan dengan konsep sederhana dan menyenangkan ini diharapkan memberikan manfaat positif bagi kedua pihak. Kerja sama ini diharapkan juga dapat berkelanjutan untuk menciptakan suasana akademis dan hunian yang kondusif dan nyaman. Dengan adanya dukungan dari segenap stakeholder dan penyelenggara, bukan tidak mungkin keterlibatan elemen-elemen masyarakat dalam mewujudkan SDGs poin 16 akan dapat membantu pemerintah pusat untuk mewujudkan keberhasilannya.

\section{SARAN}

Pada kajian berikutnya, diharapkan penanaman rasa nasionalisme juga dilakukan pada pemuda pemudi dengan usia sekolah. Metode yang dapat dilakukan dapat lebih beragam dengan memanfaatkan media digital. Hal ini dilakukan untuk menanamkan rasa nasionalisme pada remaja yang juga sangat rentan terhadap paham-paham radikalisme. Dengan demikian SDGs poin 16 akan dapat terimplementasikan dengan baik pada generasi penerus Indonesia.

Dibutuhkan adanya evaluasi mendalam dari pengelola Gateway dan penyelenggara terkait dengan kegiatan ini. Tingkat keberhasilan penanaman nilai-nilai nasionalisme juga dapat tercermin dari ketertiban dan kenyamanan lingkungan masyarakat sekitar. Feedback dari pengelola dan penghuni Gateway secara keseluruhan menjadi bagian dari evaluasi. Hasil evaluasi akan digunakan sebagai bahan tindak lanjut kegiatan berikutnya.

\section{DAFTAR PUSTAKA}

Apromico, A., Soponyono, E. S., \& Hafidz, J. 2020. Crime Prevention Strategy Of Terrorism Crime In Indonesia (Case Study In Sukoharjo). Jurnal Daulat Hukum, 2(4), 585-592.

CNN Indonesia, Perempuan dan Anak di Pusaran Terorisme, 2018.

https://www.cnnindonesia.com/nasional/2018052508 3555-12-301164/perempuan-dan-anak-di-pusaranterorisme

Djelantik, S. 2010. Terorisme: Tinjauan Psiko-Politis, Peran Media, Kemiskinan, dan Keamanan Nasional. Yayasan Pustaka Obor Indonesia.

Hadi, S. P. 2019. Sustainable Development in Indonesia: Current Problems and Future Challenges. In 3rd International Conference on Indonesian Social \& Political Enquiries (ICISPE 2018). Atlantis Press. 
Hiratsuka, M., Nakama, E., Satriadi, T., Fauzi, H., Aryadi, M., \& Morikawa, Y. 2019. An approach to achieve sustainable development goals through participatory land and forest conservation: a case study in South Kalimantan Province, Indonesia. Journal of Sustainable Forestry, 38(6), 558-571.

Ihsan, R. 2019. Peran Militer dalam Kontra-Terorisme di Indonesia. Deviance Jurnal kriminologi, 3(1), 54-68.

Jayanti, E., Muhammad, S., Nazamuddin, B., Zulham, T., \& Majid, M. 2019. Does Quality Of Life Matter For Achieving Sustainable Development Goals In Indonesia?. Regional Science Inquiry, 11(3), 119132.

Masu, R. R. 2019. Keadilan Restoratif Dalam Pembinaan Anak Yang Melakukan Tindak Pidana Terorisme (Doctoral dissertation, Universitas Airlangga).

McDermott, C. L., Acheampong, E., Arora-Jonsson, S., Asare, R. A., De Jong, W., Hirons, M., ... \& Setyowati, A. 2019. SDG 16: Peace, justice and strong institutions: a political ecology perspective.

Nimah, R., Anshori, I., \& Ikhwanuddin, M. 2019. Peran Forum Koordinasi Pencegahan Terorisme Jawa Timur Dalam Pencegahan Aksi Teror Berbasis Keluarga. MAQASID, 7(1).

Rachma, A. D. 2020. Perbandingan Hukum Pidana Terhadap Kejahatan Terorisme Di Indonesia Dan Filipina (Doctoral dissertation, Universitas Pancasakti Tegal).

Rahayu, S. W., Sugianto, F., \& Velicya, V. 2020. Penguatan Pemahaman Terhadap Pengaruh Radikalisme Sebagai Upaya Mitigasi Risiko Dan Perlindungan Anak.

Sudarmonowati, E. 2019, July. Implementation of Response to Lima Action Plan in Indonesia: Strategy and Progress in Relation to SDGs. In IOP Conference Series: Earth and Environmental Science (Vol. 298, No. 1, p. 012020). IOP Publishing.

Sumbulah, U. 2019. Perempuan dan Keluarga: Radikalisasi dan Kontra Radikalisme di Indonesia.

Tamawiwy, A. C. 2019. Bom Surabaya 2018: Terorisme dan Kekerasan Atas Nama Agama. GEMA TEOLOGIKA: Jurnal Teologi Kontekstual dan Filsafat Keilahian, 4(2), 175-194. 